\title{
Proline but not Glutathione Actively Participates in the Tolerance Mechanism of Young Schizolobium parabyba var. amazonicum Plants Exposed to Boron Toxicity
}

\author{
Paula Francyneth Nascimento SILVA, Elaine Maria Silva Guedes LOBATO*, Pêola Reis de \\ SOUZA, Helio José Medeiros dos SANTOS, Rita de Oliveira BRAGA, \\ Adriano dos Santos MOURA, Allan Klynger da Silva LOBATO** \\ UniversidadeFederalRuraldaAmazônia,Paragominas,Pará,Brazil;paulanascimento1414@gmail.com;elaine.guedes@ufra.edu.br;peolasouza.agro@gmail.com; \\ joshlio@yahoo.com.br; ritafloresta2011@hotmail.com;adrianomoura22@gmail.com; allanllobato@yahoo.com.br('correspondingauthors);
}

\begin{abstract}
Glutathione, a peptide frequently associated with the antioxidant mechanism of plants against reactive oxygen species, and proline, an amino acid whose function is related to cellular homeostasis, can both contribute to improve plant tolerance under situations of abiotic stress, such as boron toxicity. Aims of this research were to (i) quantify the oxidant and antioxidant compounds, (ii) evaluate the photosynthetic pigments, (iii) determine amino acids and PRO, and (iv) determine whether GSH and PRO contribute to the tolerance mechanisms in young Schizolobium parabyba var. amazonicum plants under B toxicity. This experiment tested five boron levels (25, 50, 100, 150 and $250 \mu \mathrm{M} \mathrm{B})$, being evaluated physiological and biochemical variables. The values reported to proline levels presented significant variation for treatments with 50, 100, 150 and $250 \mu \mathrm{M} \mathrm{B}$, with increases for the 150 and $250 \mu \mathrm{M}$ B levels, being 45.2 and $52.4 \%$, respectively. This study found that boron toxicity promoted similar behaviours in both the leaves and root, which included progressive increases in hydrogen peroxide, electrolyte leakage, amino acids and proline, and decreases in total glutathione, chlorophyll $a$, chlorophyll $b$ and total chlorophyll, confirming that proline but not glutathione actively participates in the tolerance mechanism of young Schizolobium parahyba plants exposed to boron toxicity.
\end{abstract}

Keywords: amino acid, antioxidant system, boron, chlorophyll, micronutrient, peptide

\section{Introduction}

The tree Schizolobium parahyba var. amazonicum (Huber ex. Ducke) Barneby, is a specie frequently found in tropical environments from Brazil, more specifically in the Amazon region. The botanical characteristics are rapid growth, erect trunk and few ramifications (Rosa, 2006), additionally it has economic importance because of its wood proprieties (Silva $e t$ al., 2013).

Boron (B) is an essential micronutrient to vascular plants (Koshiba et al., 2009) because this element has structural and physiological functions linked to cell wall stabilization (Brown et al., 2002), starch transport in chloroplasts (Silva et al., 2008) and lignification (Hansch and Mendel, 2009).

Stress caused by the excessive supply of B to plants frequently induces changes on the oxidant system (Molassiotis et al., 2006; Wang et al., 2011), including the overproduction of reactive oxygen species (ROS) such as the superoxide radical $\left(\mathrm{O}_{2}{ }^{-}\right)$and hydrogen peroxide $\left(\mathrm{H}_{2} \mathrm{O}_{2}\right)$ (Landi et al., 2013). The oxidative damage is characterized by the accumulation of high levels of ROS and insufficient detoxification promoted by antioxidant enzymes, such as catalase and glutathione peroxidase (Gill and Tuteja, 2010).

The chlorophylls are responsible for the photochemical and biochemical reactions during light absorption (Streit et al., 2005), whereas carotenoids play an important role related to photoprotection against excessive sunlight (Cazzonelli, 2011), both pigments work simultaneously in the photosynthetic machinery (Croce et al., 2001). However, the excessive B supply represents a problem for photosynthetic pigments, with a consequent decrease in chlorophyll contents (Papadakis $e t$ al., 2004; Tepe and Aydemir, 2011).

Glutathione (GSH) is the thiol tripeptide that is most abundant in eukaryotes (Cameron and Pakrasi, 2010) and is frequently associated to defence against ROS in plants (Foyer and Noctor, 2005; Mullineaux and Rausch, 2005), due to its ability to conjugate toxic substances that will be subsequently transported to the vacuole, thus avoiding damage in the cells (Klein et al., 2006; Yazaki, 2006). The availability of GSH is also linked to the production of phytochelatins, which are used to alleviate the toxicity by nutrients and heavy metals (Yadav, 2010). 
216

Proline (PRO) is an amino acid synthesized during nitrogen metabolism with functions related to osmoprotection (Costa et al., 2011) and cellular homeostasis (Szabados and Savouré 2010); it can contribute to improve plant tolerance under situations of abiotic stress, such as B toxicity.

Our hypothesis is that total GSH and PRO can work together simultaneously or separately in tolerance mechanism of Schizolobium parahyba plants exposed to progressively increasing boron levels. Thus, the aims of this research were to (i) quantify the oxidant and antioxidant compounds, (ii) evaluate the photosynthetic pigments, (iii) determine amino acids and PRO, and (iv) determine whether GSH and PRO contribute to the tolerance mechanisms in young Schizolobium parahybavar.amazonicum plants under B toxicity.

\section{Materials and Methods}

\section{Location and growth conditions}

The experiment was performed in the Campus of Paragominas of the Universidade Federal Rural da Amazônia, Paragominas, Brazil $\left(2^{\circ} 55^{\prime} \mathrm{S}\right.$ and $\left.47^{\circ} 34^{\prime} \mathrm{W}\right)$. The study was conducted in a greenhouse without environmental controls, and the minimum, maximum, and median temperatures were $22{ }^{\circ} \mathrm{C}, 35^{\circ} \mathrm{C}$, and $26.5^{\circ} \mathrm{C}$, respectively. The relative humidity during the experimental period varied between $70 \%$ and $90 \%$, and the photoperiod was set to $12 \mathrm{~h}$ of light. During the measurement period $(12: 00 \mathrm{~h})$, the amount of photosynthetically active radiation varied between 551 and $1,666 \mathrm{umol} \mathrm{m}^{-2} \mathrm{~s}^{-1}$.

\section{Plants, containers and acclimation}

Seeds of Schizolobium parahyba var. amazonicum (Huber ex Ducke) Barneby were placed to germinate in sand and subsequently transferred to hydroponic containers. The 15-daysold seedlings with similar aspects and sizes $(10 \mathrm{~cm}$ height and three leaves) were selected and placed in 3.0-L containers $(0.20 \mathrm{~m}$ in height and $0.14 \mathrm{~m}$ in diameter). Each container was filled with $2.8 \mathrm{~L}$ of Hoagland and Arnon nutrient solution (1950) modified in relation to the nutritional requirements of this species. The ionic force started at $25 \%$ and was modified to 50 and $100 \%$ in regular intervals of seven days, after this period the nutrient solution continued with total ionic force. Subsequently, 45-day-old plants were subjected to different B levels.

\section{Plant conduction and boron treatments}

During plant conduction, one young plant was placed in each pot. The treatments received macronutrients and micronutrients from the nutrient solution as follows: 5.71 $\mathrm{mM} \mathrm{KNO}_{3}, 2.85 \mathrm{mM} \mathrm{Ca}\left(\mathrm{NO}_{3}\right)_{2} \cdot 4 \mathrm{H}_{2} \mathrm{O}, 1.43 \mathrm{mM}$ $\mathrm{NH}_{4} \mathrm{H}_{2} \mathrm{PO}_{4}, 3.21 \mathrm{mM} \mathrm{MgSO} 4.7 \mathrm{H}_{2} \mathrm{O}, 0.71 \mathrm{mM} \mathrm{KCl}, 1.42$ $\mathrm{mM}, \quad \mathrm{KH}_{2} \mathrm{PO}_{4}, \quad 1.42 \mu \mathrm{M} \quad \mathrm{MnSO}_{4} \mathrm{H}_{2} \mathrm{O}, \quad 1.42 \mu \mathrm{M}$ $\mathrm{ZnSO}_{4} \cdot 7 \mathrm{H}_{2} \mathrm{O}, \quad 0.35 \mu \mathrm{M} \quad \mathrm{CuSO}_{4} \cdot 5 \mathrm{H}_{2} \mathrm{O}, \quad 0.35 \mu \mathrm{M}$ $\mathrm{NaMoO}_{4} \cdot 5 \mathrm{H}_{2} \mathrm{O}$, and $215.0 \mu \mathrm{M}$ NaEDTAFe. $3 \mathrm{H}_{2} \mathrm{O}$, and a boron supply limited to $25 \mu \mathrm{M} \mathrm{H} \mathrm{H}_{3} \mathrm{BO}_{3}$. To simulate the boron treatments, $\mathrm{H}_{3} \mathrm{BO}_{3}$ was also used in concentrations of $25,50,100,150$ and $250 \mu \mathrm{M}$ B. The different boron levels were applied to the young plants for 15 days, which were changed at 07:00 h over 5-day intervals and had their $\mathrm{pH}$ adjusted to $5.5 \pm 0.2$ via the addition of $\mathrm{HCl}$ or $\mathrm{NaOH}$. On the $15^{\text {th }}$ day after the treatments were started, all the plants were harvested and analysed.

\section{Extraction of oxidant and antioxidant compounds}

Hydrogen peroxide $\left(\mathrm{H}_{2} \mathrm{O}_{2}\right)$ and total glutathione (total $\mathrm{GSH}$ ) were extracted from the leaf and root tissues as described by Wu et al. (2006). An extraction mixture was prepared by homogenizing $500 \mathrm{mg}$ of fresh matter in $5 \mathrm{~mL}$ of $5 \%$ (w/v) trichloroacetic acid. Subsequently, the samples were centrifuged at $15,000 \mathrm{x}$ g for 15 min at $3^{\circ} \mathrm{C}$, and the supernatant was collected.

\section{Hydrogen peroxide determination}

For $\mathrm{H}_{2} \mathrm{O}_{2}$ detection, $200 \mu \mathrm{L}$ of supernatant and $1,800 \mu \mathrm{L}$ of reaction mixture (2.5 $\mathrm{mM}$ potassium phosphate buffer [ $\mathrm{pH} 7.0]$ and $500 \mathrm{mM}$ potassium iodide) were combined, and the absorbance was measured at $390 \mathrm{~nm}$ (Velikova et al., 2000).

\section{Total glutathione quantification}

For total GSH detection, $200 \mu \mathrm{L}$ of supernatant and 1,800 $\mu \mathrm{L}$ of reaction mixture (containing $100 \mathrm{mM}$ phosphate buffer [pH 7.6] and $0.60 \mathrm{mM}$ 2-nitrobenzoic acid) were combined, and the absorbance was measured at $412 \mathrm{~nm}$ (Wu et al., 2006).

\section{Determination of chlorophyll content}

The determination of the photosynthetic pigments was carried out with $40 \mathrm{mg}$ of leaf tissue. The samples were homogenized in the dark in the presence of $8 \mathrm{~mL}$ of methanol at $90 \%$ (Nuclear). Subsequently, the homogenate was centrifuged at $6.000 \mathrm{~g}$ for 10 minutes at $5^{\circ} \mathrm{C}$. The supernatant was removed and chlorophylls $a(\mathrm{CHL} a)$ and $b(\mathrm{CHL} b)$, total chlorophylls (total CHL) and carotenoids (CAR) were quantified using a Bel Photonics spectrophotometer (UV-M51), according to the methodology of Lichtenthaler and Buschmann (2001).

\section{Electrolyteleakage}

Electrolyte leakage was measured according to the method described by Gong et al. (1998), with minor modifications. Fresh leaves $(200 \mathrm{mg}$ ) were cut into pieces $1 \mathrm{~cm}$ long and were placed in containers with $8 \mathrm{~mL}$ of distilled deionised water. The containers were incubated in a water bath at $35^{\circ} \mathrm{C}$ for $30 \mathrm{~min}$, and the initial electrical conductivity of the medium $\left(\mathrm{EC}_{1}\right)$ was measured. The samples were boiled at $95^{\circ} \mathrm{C}$ for $20 \mathrm{~min}$ to release the electrolytes. After the samples were cooled, the final electrical conductivity $\left(E_{2}\right)$ was measured (Gong et al., 1998). The percentage of electrolyte leakage was calculated using the formula $\mathrm{EL}(\%)=\left(\mathrm{EC}_{1}\right.$ $\left./ \mathrm{EC}_{2}\right) \times 100$.

\section{Amino acids and proline}

The amino acids and proline were extracted using $20 \mathrm{mg}$ of powdered dry leaf matter, being tissue dried in oven at $65^{\circ} \mathrm{C}$ for 72 h, it incubated in $2 \mathrm{~mL}$ of deionized distilled water at $100^{\circ} \mathrm{C}$ for 30 $\mathrm{min}$. After being homogenized, the solution was centrifuged at $2000 \times g$ for $5 \mathrm{~min}$ at $20^{\circ} \mathrm{C}$ and the supernatant was removed. The quantification of the total soluble amino acids was performed at $570 \mathrm{~nm}$ according to Peoples et al. (1989), and L-asparagine + L-glutamine (Sigma Chemicals) was used as a standard. The quantification of PRO was performed after measuring the absorbance at $520 \mathrm{~nm}$ according to Bates et al. (1973) based on Lproline (Sigma Chemicals) as the standard.

\section{Experimental design}

The experiment was carried out in an entirely randomized design with five boron levels $(25,50,100,150$ and $250 \mu \mathrm{M} \mathrm{B})$. 
The experiment was assembled with five replicates for a total of 25 experimental units, with one plant in each unit.

\section{Data analysis}

The data were subjected to an analysis of variance, and significant differences between the means were determined using the Skott-Knott test at a probability level of 5\% (Steel $e t$ al., 2006). Standard deviations were calculated for each treatment. The statistical analyses were performed using SAS software.

\section{Results}

Consequences of boron toxicity on the $\mathrm{H} 2 \mathrm{O} 2$ and total GSH concentration

The $\mathrm{B}$ content in the leaves was increased after progressive $B$ treatments (Fig. 1), and a variation of $45 \%$ under the application of $250 \mu \mathrm{M}$ B was found compared with that of the control $(25 \mu \mathrm{M})$. The $\mathrm{H}_{2} \mathrm{O}_{2}$ levels in the leaves and root presented similar behaviours with significant changes being found for treatments with 150 and $250 \mu \mathrm{M}$ B. Significant increases of 59.8 and $60.7 \%$ in the leaf compared with those in the control were shown in treatments using 150 and $250 \mu \mathrm{M} \mathrm{B}$ boron exposure (Fig. $2 \mathrm{~A}$ ), respectively. For the root, significant increases were 16.6 and $27.1 \%$ (Fig. 2 B) in the treatments

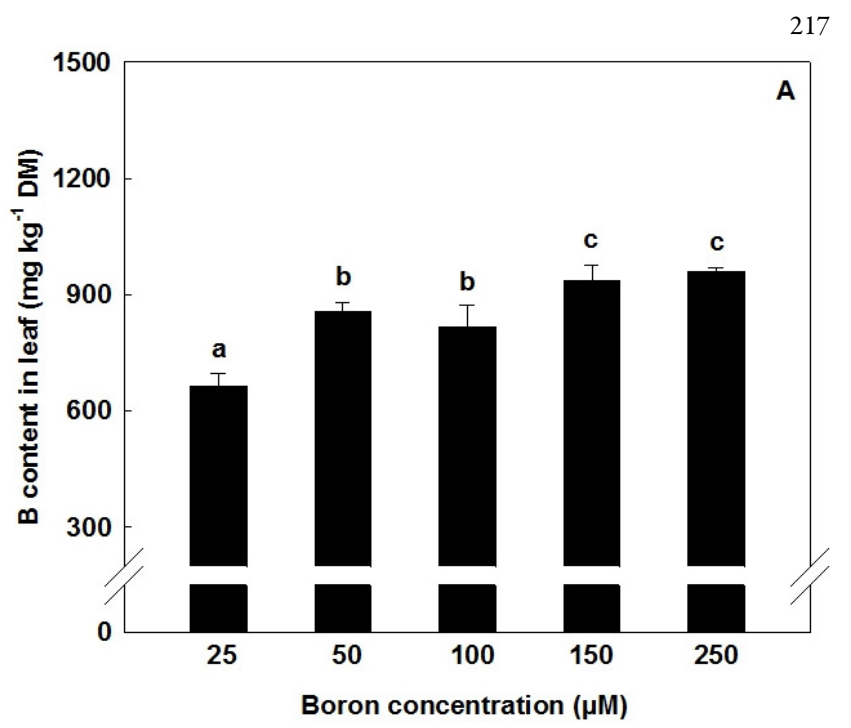

Fig. 1. Boron content in leaf of young Schizolobium parahyba var. amazonicum plants subjected to boron toxicity. Different letters for boron levels indicate significant differences from the ScottKnott test $(\mathrm{P}<0.05)$. Columns represent the mean values from 5 repetitions, and bars represent the standard deviations

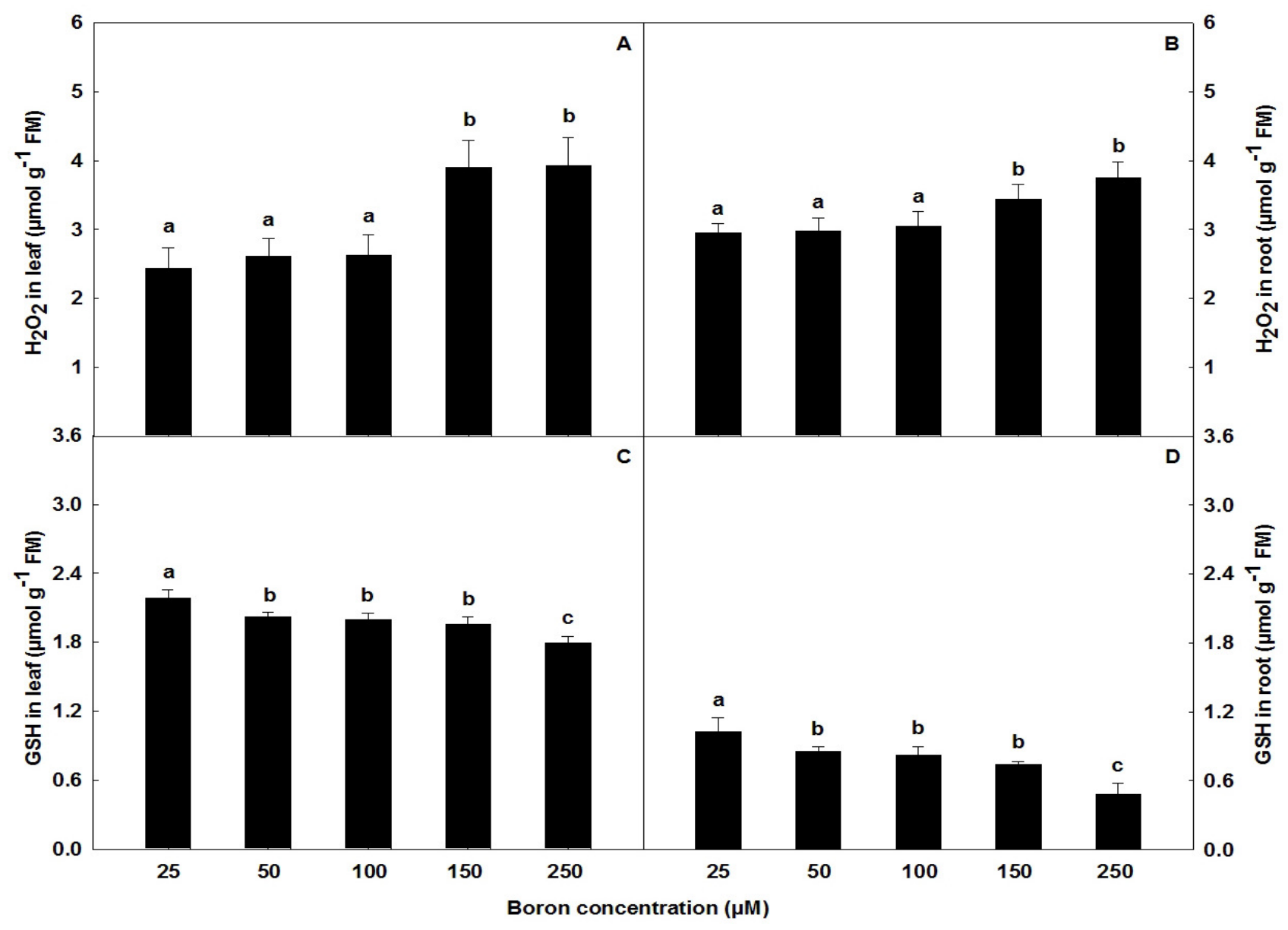

Fig. 2. Hydrogen peroxide in the leaf and root $(\mathrm{A}-\mathrm{B})$ and total glutathione in the leaf and root $(\mathrm{C}-\mathrm{D})$ of young Schizolobium parabyba var. amazonicum plants subjected to boron toxicity. Different letters for boron levels indicate significant differences from the Scott-Knott test $(P<0.05)$. Columns represent the mean values from 5 repetitions, and bars represent the standard deviations 


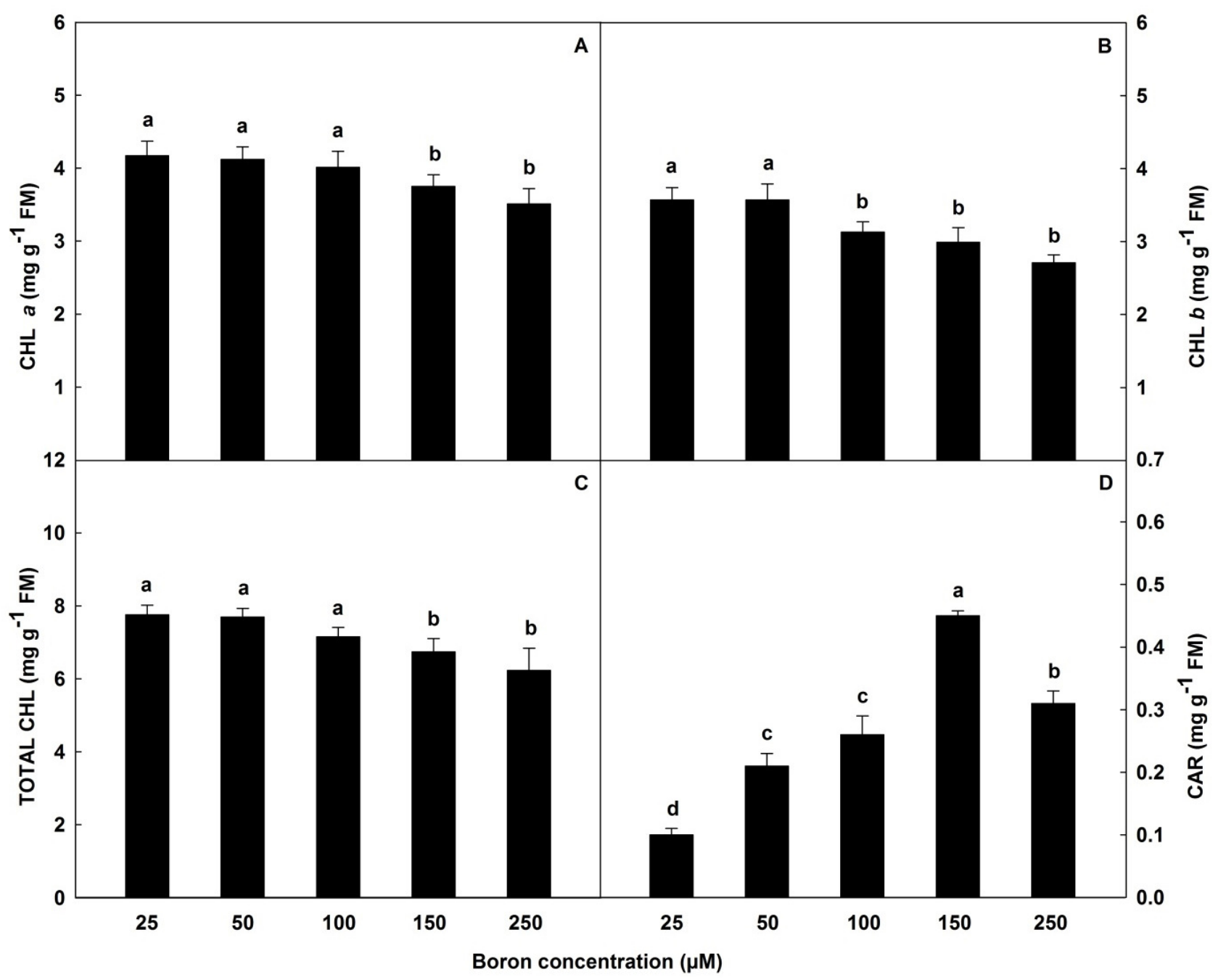

Fig. 3. Chlorophyll $a$ (A), chlorophyll $b$ (B), total chlorophyll (C) and carotenoids (D) of young Schizolobium parabyba var.amazonicum plants subjected to boron toxicity. Different letters for boron levels indicate significant differences from the Scott-Knott test $(P<0.05)$. Columns represent the mean values from 5 repetitions, and bars represent the standard deviations.

submitted to levels of 150 and $250 \mu \mathrm{MB}$ B, respectively, compared to those in the control. The total GSH levels presented significant alterations in both tissues, with a verified reduction of $17.9 \%$ for leaves exposed to $250 \mu \mathrm{M} \mathrm{B}$ (Fig. 2 C) compared to that of the control $(25 \mu \mathrm{M} \mathrm{B})$. In the root, the total GSH levels revealed significant reductions under the levels of 50, 100, 150 and $250 \mu \mathrm{M} \mathrm{B}$ (Fig. 2 D). A decrease of $53.4 \%$ was shown for the level of $250 \mu \mathrm{MB}$ compared with that of the control.

Changes in concentrations of chlorophylls and carotenoids after boron toxicity

The CHL a contents presented significant changes for treatments with 150 and $250 \mu \mathrm{M} \mathrm{B}$ (Fig. $3 \mathrm{~A}$ ), with decreases of 10.1 and $15.8 \%$, respectively, compared with control. The CHL b levels suffered interference in treatments exposed to 100, 150 and $250 \mu \mathrm{M} \mathrm{B}$ (Fig. 3 B), with decreases of 12.3, 16.2 and $24.1 \%$, respectively, when compared with $25 \mu \mathrm{M}$ B. The total $\mathrm{CHL}$ presented significant changes under the 150 and $250 \mu \mathrm{M}$ B levels (Fig. 3 C), with decreases of 13.0 and $19.6 \%$, respectively. The CAR levels of plants submitted to the progressive increase in boron levels presented significant interferences in treatments under 50, 100, 150 and $250 \mu \mathrm{M}$ B (Fig. $3 \mathrm{D}$ ), with increases of $110,160,350$ and $210 \%$, respectively, if compared to control treatment.

Interference of boron toxicity on electrolyte leakage, amino acids and proline

The progressive increase in boron levels of 50, 100, 150 and $250 \mu \mathrm{M} \mathrm{B}$ presented significant differences in values found for EL (Fig. $4 \mathrm{~A}$ ), which increased with the increase in boron levels. The highest value was obtained for the $250 \mu \mathrm{M}$ B level, which was an increase of $8.6 \%$ when compared with control. The amino acid contents in the leaves exposed to increases in boron levels (Fig. 4 B), demonstrated significant modifications in the treatments with $50,100,150$ e $250 \mu \mathrm{M} \mathrm{B}$, with increases of 30.0, $47.3,49.1$ and $50.8 \%$, respectively, if compared to $25 \mu \mathrm{M} \mathrm{B}$. The values found in the $\mathrm{PRO}$ levels presented significant variation for treatments with 50,100, 150 and $250 \mu \mathrm{M} \mathrm{B}$ (Fig. 4 C), with increases for the 150 and $250 \mu \mathrm{M}$ B levels, being 45.2 and $52.4 \%$, respectively. 


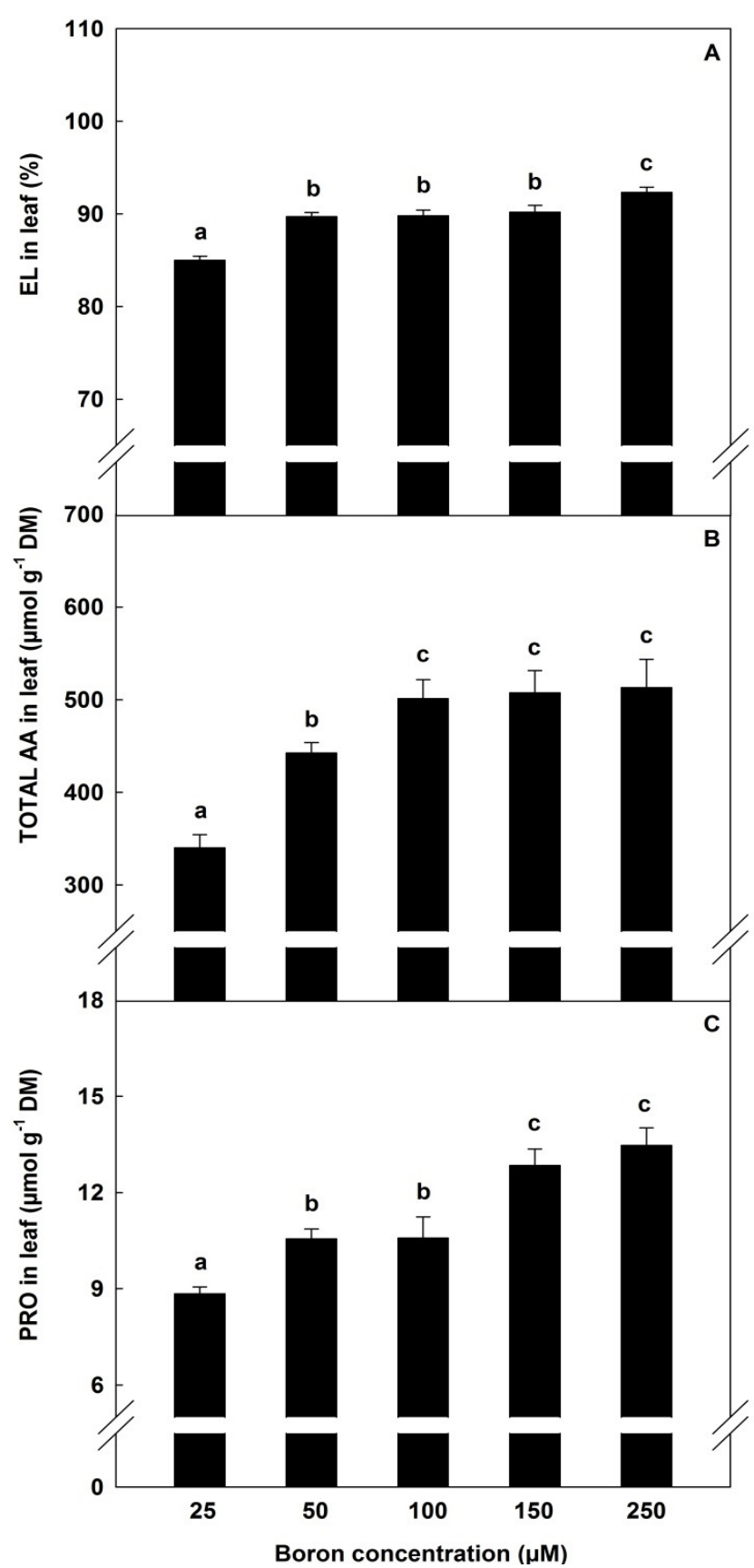

Fig. 4. Electrolyte leakage (A), total amino acids (B), and proline (C) of young Schizolobium parahybavar.amazonicum plants subjected to boron toxicity. Different letters for boron levels indicate significant differences from the Scott-Knott test $(P<0.05)$. Columns represent the mean values from 5 repetitions, and bars represent the standard deviations.

\section{Discussion}

The increased B contents in the leaves after treatments with $B$ indicate that this element was absorbed and transported to the leaves; it also reveals that the progressive $B$ levels tested in this study induced similar behaviour related to accumulations in the leaf tissue. B is a micronutrient fundamental to the growth and development of trees, such as Schizolobium parahyba, because it contributes to the lignification of the stems (Hansch and Mendel, 2009).
The $\mathrm{H}_{2} \mathrm{O}_{2}$ levels in the leaf and root presented increases that were related to the excessive production of ROS, which resulted from the toxicity caused by the excessive supply of B (Gunes et al., 2006). $\mathrm{H}_{2} \mathrm{O}_{2}$ is one of the more stable ROS and overproduction frequently occurs in plants during stress conditions (Gill and Tuteja, 2010). Molassiotis et al. (2006) obtained similar results working with Malus domestica plants cultivated in different B concentrations.

The decrease of total GSH into both tissues can be associated to insufficient actuation of this compound in the antioxidant system in response to excess $\mathrm{B}$. The boron-induced stress promoted the formation of increased amounts of $\mathrm{H}_{2} \mathrm{O}_{2}$, which suggests that total GSH does not contribute on non-enzymatic defence to remove or/and attenuate the cell oxidative damage (Wang et al., 2011; Dresler and Maksymiec, 2013). Li et al. (2012) also described a decrease in the total GSH levels in Oryza sativa plants.

The decrease in CHL a levels in plants of S. amazonicum var. parabyba subjected to excess B can be related to the minor biosynthesis of this pigment influenced by the limited absorption and transport of nitrogen (N) to the leaves. Cervilla et al. (2009) described that $\mathrm{B}$ toxicity reduces the assimilations of $\mathrm{N}$ forms, such as $\mathrm{NO}_{3}{ }^{-}$and $\mathrm{NH}_{4}^{+}$interfering also in the $\mathrm{N}$ organic concentration. This macronutrient is essential to CHL synthesis because the basic structure of this pigment is composed of one magnesium $(\mathrm{Mg})$ ion in the centre of a porphyrin ring containing four $\mathrm{N}$ atoms (Streit et al., 2005). Kent et al. (2004) studying the behaviour of Pinus banksiana plants under B toxicity also observed a decrease in the CHL a level.

The reduction in CHL $b$ must be the result of alterations in the functional state of the thylakoid membranes of the chloroplasts occasioned by the high B levels. Abiotic stresses, such as toxicity, can promote the disorganization of the thylakoids, which negatively affects the chloroplast structures and reduces the production of photosynthetic pigments, such as CHL b (Papadakis et al., 2004; Wang et al., 2011). Decrease in the CHL $b$ level were described by Han et al. (2009) working with Citrus grandis under the stress of $\mathrm{B}$ in nutrient solution.

The reduction in total CHL levels in plants under excess B was induced by the simultaneous effects related to decreases in the amounts of CHL $a$ and CHL $b$. Fávaro et al. (2011) reported decrease in CHL level in Corymbia citriodora plants exposed to B toxicity.

The increase in CAR concentration induced by B toxicity suggests that these pigments contributed to the protection mechanism of chlorophylls in young $S$. amazonicum plants. In agreement with Valladares et al. (2003), the CAR act as protection for the photosynthetic apparatus against the oxidation occasioned during stress conditions, such as B toxicity. Seth and Aery (2014) found increase in CAR studying the B effect in Vigna radiata plants.

The EL in the leaves presented an increase subsequent to $\mathrm{B}$ toxicity, and this effect is related to the accumulation of $\mathrm{H}_{2} \mathrm{O}_{2}$ in the cell. The $\mathrm{H}_{2} \mathrm{O}_{2}$ is responsible for the rupture and increase in membrane permeability, with the consequent liberation of cell contents and ions to the external medium. In agreement with Jambunathan (2010), the formation of $\mathrm{H}_{2} \mathrm{O}_{2}$ and $\mathrm{OH}^{-}$ occasioned higher rates of EL because they are highly reactive and interfere with the activities of the antioxidant enzymes. Apostol and Zwiazek (2004) observed an increase in EL when evaluating different $\mathrm{B}$ concentrations on the growth of Pinus banksiana. 
220

The total AA accumulated in the leaf must be probably associated to protease enzyme activity and concomitantly to the inhibition of the protein biosynthesis rate, due to the high $\mathrm{B}$ levels. According to Paula et al. (2013), the increases in protease activities promote the breakdown and consequent decrease of proteins, increasing the total amount of AA, which are used in the synthesis of other AA, such as PRO. Cervilla et al. (2009) found similar results evaluating the effects of the B toxicity in Solanum lycopersicum plants.

The PRO concentration was maximized, which is related to the activity of this amino acid in the detoxification process of ROS and its role in protecting membranes against lipid peroxidation (Hong et al., 2000; Cervilla et al., 2012). PRO is frequently associated as an ROS antagonist that attenuates the oxidative stress that can cause cell death. This compost protects the protein structure against denaturation and stabilizes the cell membranes during interaction with phospholipids (Cervilla $e t$ al., 2007). Contreras et al. (2011), evaluating the $\mathrm{B}$ and $\mathrm{NaCl}$ effects in Solanum lycopersicum plants, verified results similar to those found in this research.

\section{Conclusions}

This study found that B toxicity promoted similar behaviours in both leaf and root tissues, including progressive increases in $\mathrm{H}_{2} \mathrm{O}_{2}, \mathrm{EL}, \mathrm{AA}$ and $\mathrm{PRO}$ and decreases in GSH, CHL $a$, CHL $b$ and total CHL. These results confirm that PRO but not GSH actively participates in the tolerance mechanism of young Schizolobium parahyba plants exposed to B toxicity.

\section{Acknowledgments}

This research received financial support from the Fundação Amazônia Paraense de Amparo à Pesquisa (FAPESPA/Brazil) and Universidade Federal Rural da Amazônia (UFRA/Brazil) to Guedes Lobato EM. Additionally, Souza PR, Silva PFN and Santos HJM were also supported by undergraduate scholarships from Conselho Nacional de Desenvolvimento Científico e Tecnológico (CNPq/Brazil).

\section{References}

Apostol KG, Zwiazek JJ (2004). Boron and water uptake in jack pine (Pinus banksiana) seedlings. Environmental and Experimental Botany 51:145-153.

Bates LS, Waldren RP, Teare ID (1973). Rapid determination of free proline for water-stress studies. Plant and Soil 39:205-207.

Brown PH, Bellaloui N, Wimmer MA, Bassil ES, Ruiz J, Hu H, Pfeffer H, Dannel F, Römheld V (2002). Boron in plant biology. Plant Biology 4:205-223.

Cameron JC, Pakrasi HB (2010). Essential role of glutathione in acclimation to environmental and redox perturbations in the Cyanobacterium Synechocystis sp. PCC 6803. Plant Physiology 154:1672-1685.
Cazzonelli CI (2011). Carotenoids in nature: insights from plants and beyond. Functional Plant Biology 38:833-847.

Cervilla LM, Blasco B, Ríos JJ, Romero L, Ruiz JM (2007). Oxidative stress and antioxidants in tomato (Solanum lycopersicum) plants subjected to boron toxicity. Annals of Botany 100:747-756.

Cervilla LM, Blasco B, Ríos JJ, Rosales MA, Rubio-Wilhelmi MM, Rodríguez ES, Romero L, Ruiz JM (2009). Response of nitrogen metabolism to boron toxicity in tomato plants. Plant Biology 11:671677.

Cervilla LM, Blasco B, Rios JJ, Rosales MA, Sánchez-Rodríguez E, RubioWilhelmi MM, Romero L, RuizJM(2012).Parameters symptomatic for boron toxicity in leaves of tomato plants. Journal of Botany 2012:1-17.

Contreras C, Montoya A, Pacheco P, Martinez-Ballesta MC, Carvajal M, Bastias $\mathrm{E}$ (2011). The effects of the combination of salinity and excess boron on the water relations of tolerant tomato (Solanum lycopersicum L.) cv. Poncho Negro, in relation to aquaporin functionality. Spanish Journal of Agricultural Research 9:494503.

Costa RCL, Lobato AKS, Silveira JAG, Laughinhouse IV HD (2011). ABA-mediated proline synthesis in cowpea leaves exposed to water deficiency and rehydration. Turkish Journal of Agriculture and Forestry 35:309-317.

Croce R, Müller MG, Bassi R, Holzwarth AR (2001). Carotenoid-tochlorophyll energy transfer in recombinant major light-harvesting complex (LHCII) of higher plants. I. Femtosecond transient absorption measurements. Biophysical Journal 80:901-915.

Dresler S, Maksymiec W (2013). Capillary zone electrophoresis for determination of reduced and oxidized ascorbate and glutathione in roots and leaf segments of Zea mays plants exposed to $\mathrm{Cd}$ and $\mathrm{Cu}$. Acta Scientiarum Polonorum Hortorum Cultus 12:143-155.

Fávaro EA, Vitorino ACT, Daniel O, Novelino JO (2011). Boron and magnesium on Corymbia citriodora production and chlorophyll content. Floresta 41:3946.

Foyer $\mathrm{CH}$, Noctor $\mathrm{G}$ (2005). Redox homeostasis and antioxidant signaling: a metabolic interface between stress perception and physiological responses. The PlantCell 17:1866-1875.

Gill SS, Tuteja N (2010). Reactive oxygen species and antioxidant machinery in abiotic stress tolerance in crop plants. Plant Physiology and Biochemistry 48: 909-930.

Gong M, Li YJ, Chen SZ (1998). Abscisic acid-induced thermotolerance in maize seedlings is mediated by calcium and associated with antioxidant systems. Journal of Plant Physiology 153:488-496.

Gunes A, Soylemezoglu G, Inal A, Bagci EG, Coban S, Sahin O (2006). Antioxidant and stomatal responses of grapevine (Vitis vinifera $\mathrm{L}$.) to boron toxicity. Scientia Horticulturae 110:279-284.

Han S, Tang N, Jiang H, Yang L, Li Y, Chen L (2009). $\mathrm{CO}_{2}$ assimilation, photosystem II photochemistry, carbohydrate metabolism and antioxidant system of citrus leaves in response to boron stress. Plant Science 176:143-153.

Hansch R, Mendel RR (2009). Physiological functions of mineral micronutrients $(\mathrm{Cu}, \mathrm{Zn}, \mathrm{Mn}, \mathrm{Fe}, \mathrm{Ni}, \mathrm{Mo}, \mathrm{B}, \mathrm{Cl})$. Current Opinion in Plant Biology 12:259-266.

Hong Z, Lakkineni K, ZhangZ, Verma DPS (2000). Removal of feedback inhibition of $\boldsymbol{\Delta}^{1}$-pyrroline-5- carboxylate synthetase results in increased proline accumulation and protection of plants from 
osmotic stress. Plant Physiology 122:1129-1136.

Hoagland DR, Arnon DI (1950). The water culture method for growing plants without soils. Berkeley: California Agricultural Experimental Station.

Jambunathan N (2010). Determination and detection of reactive oxygen species (ROS), lipid peroxidation, and electrolyte leakage in plants. In: Sunkar R (Ed). Plant Stress Tolerance, 1st edn. Humana Press, New York pp 291-297.

Kent GA, Janusz JZ (2004). Boron and water uptake in jack pine (Pinus banksiana) seedlings. Environmental and Experimental Botany 51:145-153.

Klein M, Burla B, Martinoia E (2006). The multidrug resistance-associated proteins (MRP/ABCC) subfamily of ATP-binding cassette transporters in plants. Federation of European Biochemical Societies Letters 580:1112-1122.

Koshiba T, Kobayashi M, Matoh T (2009). Boron nutrition of tobacco BY-2 Cells. V. oxidative damage is the major cause of cell death induced by boron deprivation Plant and Cell Physiology 50:26-36.

Landi M, Remorini D, Pardossi A, Guidi L (2013). Boron excess affects photosynthesis and antioxidant apparatus of greenhouse Cucurbita pepo and Cucumis sativus. Journal of Plant Research 126:775-786.

Li P, Song A, Li Z, Fan F, Liang Y (2012). Silicon ameliorates manganese toxicity by regulating manganese transport and antioxidant reactions in rice (Oryza sativa L.). Plant and Soil 354:407-419.

Lichtenthaler H, Buschmann C (2001). Chlorophylls and carotenoids: measurement and characterization by UV-VIS Spectroscopy. Current Protocols in Food Analytical Chemistry F.4.3.1-F.4.3.8.

Molassiotis A, Sotiropoulos T, Tanou G, Diamantidis G, Therios I (2006). Boron-induced oxidative damage and antioxidant and nucleolytic responses in shoot tips culture of the apple rootstock EM 9 (Malus domestica Borkh). Environmental and Experimental Botany 56:54-62.

Mullineaux PM, Rausch T (2005). Glutathione, photosynthesis and the redox regulation of stressresponsive gene expression. Photosynthesis Research 86:459-474.

Papadakis IE, Dimassi KN, Bosabalidis AM, Therios IN, Patakas A, Giannakoula A (2004). Boron toxicity in 'Clementine' mandarin plants grafted on two rootstocks. Plant Science 166:539-547.

Paula MT, Santos Filho BG, Cordeiro, YEM, Conde RA, Neves PAPFG (2013). Ecophysiology the brazilian mahogany (Swietenia macrophylla King) agroforestry systems in Santa Barbara-Pa. Enciclopédia Biosfera 9:813824.

Peoples MB, Faizah AW, Reakasem B, Herridge DF (1989). Methods for evaluating nitrogen fixation by nodulated legumes in the field. Monograph, Australian Centre for International Agricultural Research, Australia.
Rosa LS (2006). Botanical, anatomical and technological characteristics of Paricá (Schizolobium amazonicum Huber ex. Ducke). Amazonian Journal of Agricultural and Environmental Sciences 46:63-79.

Seth K, Aery NC (2014). Effect of boron on the contents of chlorophyll, carotenoid, phenol and soluble leaf protein in mung bean, Vigna radiata (L.) Wilczek. Proceedings of the National Academy of Sciences, India. Section B: Biological Sciences 84:713-719.

Silva DH, Rossi ML, Boaretto AE, Nogueira NL, Muraoka T (2008). Boron affects the growth and ultrastructure of castor bean plants. Scientia Agricola 65:659-664.

Silva JJN, Cardoso GV, Júnior FGS, Stangerlin DM (2013). Technological characterization of Schizolobium amazonicum wood for kraft pulp production. Brazilian Journal of Wood Science 4:33-45.

Steel RGD, Torrie JH, Dickey DA (2006). Principles and procedures of statistics: a biometrical approach. USA: Academic Internet Publishers, Moorpark.

Streit NM, Canterle LP, Canto MW, Hecktheuer LHH (2005). The chlorophylls. Ciência Rural 35:748-755.

Szabados L, Savouré A (2010). Proline: a multifunctional amino acid. Trends in Plant Science 15:89-97.

Tepe M, Aydemir T (2011). antioxidant responses of lentil and barley plants to boron toxicity under different nitrogen sources. African Journal of Biotechnology 10:10882-10891.

Valladares F, Hernández LG, Dobarro I, García-Pérez C, Sanz R, Pugnaire FI (2003). The ratio of leaf to total photosynthetic area influences shade survival and plastic response to light of green-stemmed leguminous shrub seedlings. Annals of Botany 91:577-584.

Velikova V, Yordanov I, Edreva A (2000). Oxidative stress and some antioxidant system in acid rain treated bean plants: protective role of exogenous polyamines. Plant Science 151:59-66.

Wang JZ, Tao ST, Qi KJ, Wu J, Wu HQ, Zhang GSL (2011). Changes in photosynthetic properties and antioxidative system of pear leaves to boron toxicity African Journal of Biotechnology 10:19693-19700.

Wu QS, Xia RX, Zou YN (2006). Reactive oxygen metabolism in mycorrhizal and non-mycorrhizal citrus (Poncirus trifoliate) seedlings subjected to water stress. Journal of Plant Physiology 163:1101-1110.

Yadav SK (2010). Heavy metals toxicity in plants: An overview on the role of glutathione and phytochelatins in heavy metal stress tolerance of plants. South African Journal of Botany 76:167-179.

Yazaki K (2006). ABC transporters involved in the transport of plant secondary metabolites. Federation of European Biochemical Societies Letters 580:1183-1191. 